IGOR DEIANA

Università per Stranieri di Perugia

Stefania Spina

Università per Stranieri di Perugia

\title{
Second language learning for vulnerable adult migrants: The case of the Italian public school
}

\begin{abstract}
Over the last years, thousands of asylum seekers and refugees have arrived in Italy, including a large number of teenagers without any adult caregivers and women. A significant part of them is placed in the Italian language courses for foreigners organised by the Provincial Centre for Adult Education, commonly called CPIA (Centro Provinciale per l'Istruzione degli Adulti). This paper addresses the exploration of the language testing and assessment of the courses organized by this institution. With the aim of evaluating these aspects, the paper concentrates on the CPIA, its teachers, and its students. Focusing on CPIA's language courses, we investigate the language testing and assessment carried out at the beginning and at the end of the language courses. Thanks to these observations, the paper tries to identify some critical aspects and to understand their causes.

KEYWORDS: adult foreign language education, vulnerable adult migrants, second language adult learners, illiterate students, teaching Italian as a second language, second language teachers, language teacher training, language testing and assessment.
\end{abstract}

\section{INTRODUCTION}

In recent years, the arrival of a large number of asylum seekers and refugees has had a considerable impact on European societies. Because of these migration flows the European idea of acceptance and reception of new European residents has changed. In fact, consisting of a wide variety of people coming from Africa and the Middle East, this new mass migration has had a significant influence on western European societies. As a consequence, also the national school systems in this world region seems to have been strongly affected.

It is easy to notice this phenomenon in the everyday life of Italian schools. On the one hand it must be underlined that the lack of consistent and valid political actions aimed at facilitating the linguistic and social integration of these new 
European residents. Despite these obstacles, it cannot be denied that the Italian school and, in particular, its teachers work strongly to support this process of integration. It is clear that this sudden change in our society has brought issues to the attention of educators and teachers, issues that they had never taken into account before. From primary school to university, every level of education has entered novel, interesting, and sometimes not easy to manage situations.

This paper addresses the exploration of the courses of Italian as a second language offered by the Provincial Centre for Adult Education, commonly known as CPIA (Centro Provinciale per l'Istruzione degli Adulti). That CPIA plays a central role in migrants' development of linguistic and social skills is evident. Its language classes (Percorsi di alfabetizzazione e apprendimento della lingua italiana), have a fundamental role in the lives of migrants. Italian language classes are one of the most important occasion to learn and improve the language of the host country, they can support migrants on the integration into the host society. The key role of this classes is undeniable also because migrants are required to acquire linguistic abilities for the purposes of entry, residence and citizenship (ALTE 2016).

Based on the findings of a survey presented to A23 teachers, who are specialised in teaching Italian as a second language, this paper focuses on CPIA's language testing and assessment. Our aim is to understand how this institution works and to identify possible problems regarding its functioning.

After the Introduction, Section 2 explains the methodology used for the study. Sections 3,4 and 5 provide the background information useful to understand the Italian language course system for adults. In Section 6, after having discussed the central role of assessment and testing, we provide an overview of our findings. Section 7 contains final reflections and conclusions.

\section{RESEARCH METHOD}

Our reflections are based on the data collected by means of an anonymous survey sent to all the 130 CPIAs during the school year 2018/2019. This survey, entitled A23: Who? How? Where? When? Why? (A23: Chi? Come? Dove? Quando? Perché?), is part of a wider research meant to study and measure the effectiveness of the CPIA's language courses. The survey was aimed at detailing the role played by A23 teachers in CPIA's courses and investigating the CPIA's teaching and didactic practices.

Conducted by means of a self-administered online questionnaire submitted from February to April 2019, it involved 76 A23 teachers: 61 of them answered questions related to the school year 2017/2018 and 69 answered questions about the school year 2018/2019. 
Consisting of open-ended and closed-ended questions, the questionnaire is structured into six parts. The first is dedicated to personal information (age and gender), the second focuses on teacher training. The third one investigates the experiences which teachers had before working as A23 in CPIA. Sections four and five, each dedicated to one of the school years investigated, include several questions dedicated to the courses of education provided in CPIAs. The last section consists of an open-ended question, gathering personal reflections about the role played by A23 teachers on CPIA courses.

Thanks to the statements made by the sample group of A23 teachers, in particular the ones from Sections four and five, our data offers a critical point of view coming from experts in language teaching and learning (specifically CPIA's courses of Italian as a second language).

\section{CPIA}

CPIA (Centro Provinciale per l'Istruzione degli Adulti) is a school aimed to increase education levels of the adult population. The first Italian public institution responsible for adult education was the CTP (Centro Territoriale Permanente). Established by Ministerial Order No. 455 in July 1997, the CTP can be considered the predecessor of the CPIA. In fact, as it has been pointed out by Orazio Colosio (2015), on account of the several CTP s' weak points the Italian adult education system needed to be reformed and reorganised. This reorganization begun in 2006 and was complex, but eventually resulted in the establishment of the CPIA in October 2012 by the Decree of the President of the Italian Republic No. 263 (Porcaro 2019). The CPIA started its work in the school year 2015/2016. In addition to the Italian language courses for foreigners (Percorsi di alfabetizzazione e apprendimento della lingua italiana) the CPIA includes also the lower secondary school courses (Percorsi di istruzione di primo livello) and the upper secondary school courses (Percorsi di istruzione di secondo livello).

Emilio Porcaro (2019) underlines that thanks to the establishment of CPIA for the first time "Italian language courses for foreigner people" were officially included in the curriculum of the Italian public school. Before this subject had been taught as an extra or additional activity. Furthermore, the important role that CPIAs occupy in procedures required to obtain the long-term residence permit need to be underscored, which is linked to fulfilment of the requirements of the Integration Agreement. CPIAs play a central role both in the case of the Italian A2 level test for the issuance of a permit for EU long-term residents, and for the oral test linked to the Integration Agreement. In fact, these tests are designed and administered by CPIA's teachers by adopting specific guidelines. 


\section{CPIA'S STUDENTS}

As pointed out by Giuseppe Enna (2019) the development of intensive migration flows in the past years has modified the composition of CPIA learners, both quantitatively and qualitatively. The arrival of people from various African countries (such as Nigeria, Eritrea, Somalia, and Gambia) or from Middle East countries (mainly from Afghanistan, Syria, and Iraq) has powerfully influenced the CPIAs. The wide variety in the students' profiles has become more complex and pronounced than what it used to be. Consequently, teachers have to consider this new variety of learners when reconsidering and rethinking their teaching plans.

That diversity can significantly influence the planning and development of an educational project and the choice of a pedagogical approach is undeniable. In order to delineate the students' profile, teachers have to consider many aspects such as the country of origin, their ethnicity, age, gender, religion, personal history, time of arrival in the host country, administrative and financial situation, social network, literacy and educational background. Related to one another, all of the above-mentioned aspects are very important. With regards to CPIA students, our reflections focus on two essential points: personal history and literacy combined with schooling background.

It is important to underline that a significant number of learners was subject to stressful experiences. Therefore, teachers should be empathetic and cautious when approaching them. Many of such students are teenagers without any adult caregivers, the so-called "unaccompanied minors", or women. They often cope with traumatic experiences without the fundamental support of their friends and relatives. As shown by Thomas Fritz and Dilek Donat (2017), all of these obstacles have a considerable impact on learners, also many highly motivated students face difficulties in learning. It is easy to understand that daily life and previous history constitute a real problem for a successful learning. For this reason, teachers should take them in consideration when they develop their educational projects.

Educational background and literacy constitute the second issue to be considered. As underlined by Mari D'Agostino (2017a, 2017b), there is a noticeable diversity among learners in terms of their level of education. A significant number is composed of people without much formal education or training and without enough writing or reading skills. Another considerable group is constituted by vulnerable students with little formal education who have less than eight years of schooling. Furthermore, as pointed out by Fernanda Minuz, Lorenzo Rocca and Alessandro Borri (2019), for years illiterate students were not taken into consideration. It was taken for granted that that foreign languages had to 
be studied by literate people. This can be easily seen in the Common European Framework of Reference for Languages (the CEFR, Council of Europe 2001) and its Companion volume with new descriptors (Council of Europe 2018). The considerable increase in the number of people seeking refuge in Europe have begun to contradict this belief. The high number of learners with a level of literacy and proficiency lower than the ones described in the above-mentioned publications has stressed and emphasised this weakness. Now, it's finally clear that adult who are beginner readers and writers and illiterate adults have to face many difficulties, difficulties that in the past years were not even conceivable in the field of second language teaching (Annalisa Brichese 2019). Rola Naeb and Marta Young-Scholten (2017: 420) highlighted that learners "with little or no formal education or home language literacy take up to eight times longer than educated adults to reach the A1 of the Common European Framework of Reference for Languages". Learners without much formal education and without enough reading or writing need a specific support with the aim of successfully achieving their schooling goals.

Researchers contend (e.g. Borri et al. 2014) that literacy development in L2 is an articulated and complex phenomenon. According to Alessandro Borri and Fernanda Minuz (2017), it is possible to identify four stages of illiteracy that can be related to the same number of learning profiles: Pre-Alpha A1, Alpha A1, Pre-A1 and A1. Pre-Alpha A1 are non-educated adults, whose first language is not written or is not the medium of schooling in their country of origin. Alpha $\mathrm{A} 1$ are adults who are not able to write and read in their first language and have never been educated. Pre-A1 students are adults who have received a low level of education and / or partially lost their literacy skills because they have not written and read for some time. A1 students correspond to the A1 profile described on the CEFR level. In addition, it has been argued by Alessandro Borri, Fernanda Minuz, L. Rocca and C. Sola (2014) that many factors such as the characteristics of first language can have a strong influence in literacy development in L2. A valid example is the writing system. These are just a few of the various elements that can influence the improvement of literacy.

\section{CPIA'S TEACHERS}

Based on the composition of CPIA learners, it is obvious that CPIA teachers have to be well trained and skilled to provide language support to their students. As recently pointed out by Fabio Caon (2019), there is a knowledge and skills set that teachers need to support vulnerable students with little or no formal education. They should be able to plan and use teaching methods that facilitates such 
learners' active participation. They should have the ability to choose and create appropriate materials for low-educated immigrant adults so as to improve students' language skills. As for multimodal materials for literacy, teachers should use, modify and simplify them to meet migrant learners' needs. Being able "to guide learners in the process of developing reading and writing strategies that they can apply independently outside the classroom and in situations involving written language" (Naeb \& Young-Scholten 2017: 422) is another important skill. According to Rola Naeb and Martha Young-Scholten (2017), teachers should be able to understand the learners' backgrounds, current situations and specific needs so as to consider these when planning their instruction. Taking into consideration the role that the vast life experience in a multilingual environment and the exposure to learning a diversity of new languages the students had is a valid example. In the same way, thanks to continuing professional development, teachers should have a sound awareness of current teaching materials suitable for vulnerable learners' support and an up-to-date knowledge of the most recent findings made by researchers working in the field of language teaching. With the aim of developing an articulated and efficacious teaching as presented above, it is clear that specific knowledge is required.

Having described the profile of a model CPIA teacher, it is interesting to see who teaches Italian L2 at the CPIA. CPIA's language courses school staff consists of primary school teachers and A23 teachers. The majority are primary school teachers who do not have to specialise in teaching a second language. Since September 2017, A23 teachers have also been working at the CPIA. Unfortunately, although having successfully completed a structured course on teaching Italian as a foreign or second language, A23 teachers are only a little part of the CPIAs' school staff. Despite this, the establishment of the A23 teachers was very important because for the first-time teachers specialised in teaching Italian as an L2 have been included in the Italian public school staff. In fact, as Maria G. Lo Duca (2013) claims, for a long time the Italian school had not had staff who featured enough professionalism useful to face problems linked to learning Italian as a second language. As underlined by Giulia Grosso (2013) and Chiara Andreoletti (2018), until the recruitment of A23 teachers the Italian school tried to face this situation doing its best with the resource and the teachers' professionalism available. On the one hand, often not-well-trained teachers had to cater for the foreign students' needs. On the other hand, when skilled and trained teachers were required, they were recruited from specific calls outside the teacher's school staff. Donatella Troncarelli and Matteo La Grassa (2018) underscore that the language courses organised thanks to the funding of the FEI (Fondi europei per l'integrazione) and FAMI (Fondo asili migrazione e integrazione) are valid examples of the efforts undertaken. 
The rules concerning teachers' employment in CPIAs provide that A23 teachers give the lower secondary school courses (Percorsi di istruzione di primo livello). However, according to our survey conducted in the 130 Italian CPIAs, it seems that this rule is not followed (see Figure 1).

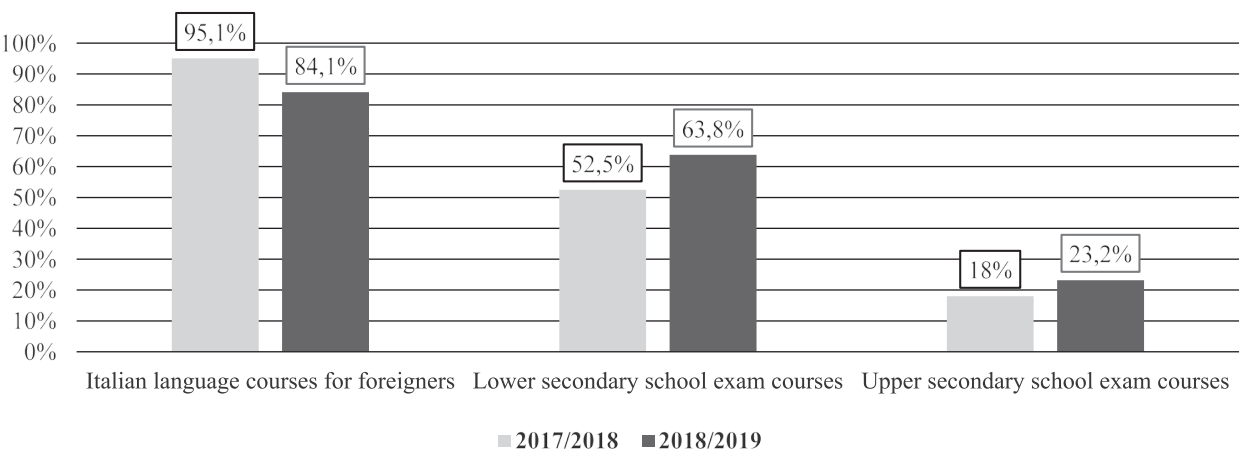

Figure 1. A23 teachers in CPIA courses. Which courses do they teach?

Figure 1 shows that in the school years 2017/2018 and 2018/2019 the majority of A23 teachers taught the language courses. Claiming they had the titles and skills to do so, A23 teachers objected to following the regulations and informally changed them. This illustrates how the school tried to change rules that did not seem to work. Furthermore, based on the statements made by some A23 teachers interviewed, it can be inferred that CPIA staff is not well organised. A good example reported by several A23 teachers is the fact that some CPIA headmasters declared they did not know how to employ A23's professional capacity.

Moreover, the data obtained by our survey allows describing and discussing some weak aspects of CPIA staff. A23 teachers were asked to judge their professional relationship with their colleagues (both primary school and A23). The average mark for primary school teachers was low: $6 / 10$ for the school year $2017 / 2018$, and $6.6 / 10$ for the school year 2018/2019. In contrast, the average mark for A23 teachers was higher: 7.9/10 for the school year 2017/2018 and $7.8 / 10$ for the school year 2018/2019. A23 teachers generally criticise primary school teachers for their lack of skills and knowledge. Primary school teachers are said to fail to meet quality standards. In detail, it appears that many primary school teachers seem to ignore the most important fundamentals of second language teaching. Some are said not to fully know and understand the syllabus or the CEFR. In addition, our data shows that almost $90 \%$ of the A23 teachers interviewed seem to find some differences in the knowledge, skills and practices between them and the primary school teachers. 
Even if a large number of the observations collected by us are negative, we prefer not to generalise. There are also some positive remarks. In fact, it seems that there are also many primary school teachers who, thanks to their experience and training in teaching Italian as a second language, are well qualified and competent.

\section{LANGUAGE TESTING AND ASSESSMENT}

The study of CPIA courses of Italian as a second language (Percorsi di alfabetizzazione e apprendimento della lingua italiana $)^{1}$ and the language testing and assessment activities employed in them is very interesting and stimulating. Not only are these activities important to delineate the learners' profile, to find the most suitable teaching group, and to tailor the didactic planning, but they also have a key role in migration and integration policies.

It is increasingly evident that migrants are required to acquire linguistic abilities for the purposes of entry, residence and citizenship. This stands for linking immigration and residency to language test results. As in many European countries (Rocca, Carlsen \& Deygers 2020), in Italy people are asked to certify their language knowledge to obtain the temporary residency, a long-term residence permit and the Italian citizenship. As stated in the Decree of the President of the Italian Republic no. 179 of September 2011, "migrants who lack documentation confirming that they meet the requirements of the Integration Agreement" (Machetti \& Rocca 2017: 214) must take and pass an oral test which certifies their knowledge of the Italian society and a level of knowledge of Italian corresponding to level A2. Furthermore, as referred to the Law no. 94/2009 and the Ministerial Decree of 4 June 2010, "non-EU citizens who apply for a permanent residence permit are asked to take an official language test in order to demonstrate that they have reached CEFR level A2" (Masillo 2017: 258). In addition, the Law no. 132/2018 introduced a language requirement also for the granting of the citizenship. In fact, in cases where people ask for the acquisition of the Italian citizenship following the marriage with an Italian person or after a long period of legal residence in Italy², they are required to know Italian at least at level B1 according to the CEFR.

Over the last decades the connection between legalising residence in a country and certifying linguistic skills has gained attention in the academic

\footnotetext{
${ }^{1}$ It is important to remember that these courses are aimed to the achievement of the level A2.

${ }^{2}$ Foreigners can apply for the Italian citizenship after ten years of legal residence in Italy, decreased to five years in case of foreign nationals being granted the status of stateless persons or refugees and to four years for nationals residing in EU Countries.
} 
world. As argued by Elana Shohamy $(2001,2009,2017)$, in the context of immigration language tests can have a significant impact for test takers and for society. These consequences, which need to be examined and evaluated, are undeniable and must be taken into consideration when tests are used as instruments of policy. Indeed, it has been shown that tests of high stakes have strong implications for the future of foreigners and, in particular, of migrant people. Since 2002, thanks to the establishment of the Language Assessment for Migration and Integration (LAMI) Group, researchers have been engaged in raising awareness of the impact of language testing policy, and to ensure test fairness (ALTE 2016).

\subsection{The assessment: The placement}

The assessment of language competence of future students is one of the most important activity made at the beginning of CPIA language courses. During this first part of the course, called accoglienza (welcoming), teachers have to explain the learning objectives of the course and profile students. As establishes by the CPIA language course regulation, the accoglienza last 20 hours (10\% of the total amount).

As recently pointed out by Lorenzo Rocca (2019), the accoglienza is the most important moment in the creation of the class. In the case of vulnerable students with little or no formal education, the accoglienza is a central moment. In fact, teachers have the opportunity to test their student's abilities in writing and reading and define their level of literacy and schooling. Since a large number of migrants is linguistically and socially disadvantaged, it is clear that the opportunity to access an Italian language course represents a valuable opportunity for them. For this reason, the assessment made during the accoglienza is fundamental. Indeed, an assessment that fails to meet quality standards can have dramatic consequences on the learning of the more vulnerable students. Their lack of motivation to learn and the loss of interest in schoolwork are just two consequences which do not facilitate their linguistic and social integration. Based on the findings of our survey, it is possible to evaluate the accoglienza of the Italian language classes and to identify some critical aspects.

In general, a significant percentage of students $(36,3 \%)$ who are not able to understand and follow the class was found. One of the several causes of this state of matters can be that the placement assessment was not performed carefully. Placing students in a class corresponding to their language level is not easy. It must be remembered that placement activities, as with every kind of assessment, should be carried out by skilled teachers following set procedures. For instance, teachers should be able to design and use specific and reliable tools in 
which aspects such as gender, age, first language, religion, ethnicity, motivation, schooling, and literacy are all taken into consideration.

For the accoglienza the CPIA's regulation provides the Patto Formativo (Training Agreement). Designed for the elementary and lower secondary school courses held by the CTP at the end of nineties, the Patto Formativo exemplifies the cornerstone of the tailored learning. Improved and developed during the CTP's reforme, the Patto Formativo is a useful and valid tool that facilitates learners to share their knowledge and experience. Currently there is no national standard for the accoglienza. There is not a shared set of procedures that teachers have to follow, they are free to decide how to carry out these tasks. In spite of it, if the accoglienza is performed in a valid way, at the end of the 20 hours teachers should generally know their students 'needs to create the class. In this regard, it is obvious that teachers have to be well trained and skilled to do so in such a short period of time.

It is clear that many variables influence the quality of the accoglienza. One important aspect is the lack of valid and shared practices. CPIAs are still not equipped with national and shared guidelines concerning the accoglienza. This lamentable state of affairs is confirmed by our data. Almost a third of the A23 interviewed declared that, in their CPIA, procedures for the accoglienza are rarely discussed and shared among the staff members and that, instead, teachers rely on their experiences. Furthermore, it is quite obvious that the quality of the $a c$ coglienza depends on the appropriate and suitable training of teachers. However, due to a shortage of training opportunities available for teachers, the procedures for the accoglienza fails to meet quality standards. A considerable number of the A23 teachers argued that the major obstacle to a reliable and valid placement assessment is the poor-quality training of primary school teachers.

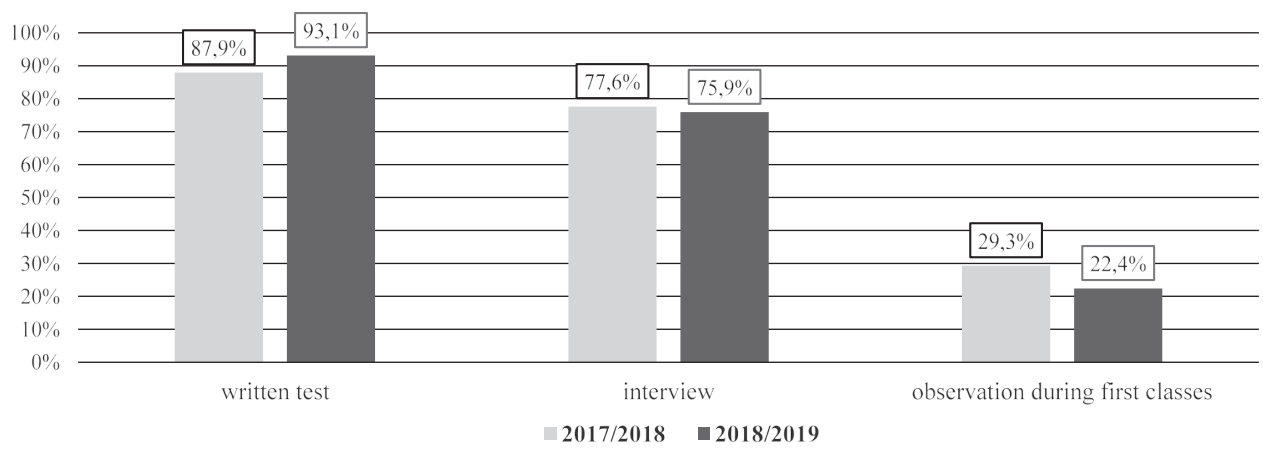

Figure 2. CPIA's placement assessment methods 
As far as placement activities are concerned, our data gives an interesting insight into the CPIA. Writing tests features the highest percentage and are found to be the most frequently used tool. Interviews are used by three quarters of the CPIAs (77,6\% for the school year 2017/ 2018 and 75,9\% for the school year 2018/2019). Class observation features very low percentages: $29,3 \%$ for the school year 2017/2018, and 22,4\% for the school year 2018/2019 (see Figure 2). According to Lorenzo Rocca (2019), a structured interview integrated, if necessary, with a written test could be a useful tool to define the student's profile. Observation during the first classes is a valuable tool for determining whether the placement was performed in a valid way or if some changes are needed.

Over the last years a great number of valid tools for language placement assessment has been designed and published. Having a knowledge of recent findings made by researchers can help teachers to refine and upgrade their placement assessment. An example is the Language support for adult refugees: A Council of Europe toolkit (Council of Europe 2017). It has been developed to respond to the challenges posed by unprecedented migration flows as part of the project Linguistic Integration of Adult Migrants of the Council of Europe's major Programme on language policy.

\subsection{The final exam}

It must be remembered that language tests and their results are used as instruments of policy and have consequences for test takers. With regards to non-EU citizens, tests can be used to take high-stakes decisions, such as whether that person is granted a residence permit or citizenship (Elana Shohamy 2001, $2009,2017)$. These dramatic consequences should be taken into consideration when tests are produced, so as to underpin test validity, objectivity, reliability, and fairness.

As explained by Paola Masillo (2017), Italy currently lacks a national standard test. In November 2010 the Ministry of Education, University and Research and the Ministry for Home Affairs signed an agreement according to which the CPIAs are given some instructions, but it is their teachers' responsibility to prepare and administrate the tests (Machetti \& Rocca 2017).

To understand how each CPIA develops and creates its own end-of-course exam of the Italian language courses for foreigners, our 76 A23 teachers were asked to share their experience. Our survey showed considerable differences in terms of test design among the CPIAs. The first interesting aspect is that the tests consist of a variable number of sections, three or six, therefore evaluating 
language skills diversely. Listening, reading and writing are always present, whereas grammar, vocabulary, and speaking are found in just a low number of tests. Secondly and accordingly, this situation entails problems of reliability and validity. In brief, it is not possible to compare the end-of-course exams of the Italian language courses for foreigners organised by all 130 Italian CPIAs.

Paola Masillo (2017) voices similar criticisms concerning the A2 level test necessary to obtain the permit for EU long-term residents prepared by the CPIA in cooperation with the local prefecture. Since this exam bears many resemblances to the one administrated at the end of CPIA courses, Masillo's findings are particularly significant. It is indeed possible to appreciate important similarities to our data. The Italian researcher found a lack of fairness and transparency, which is confirmed by the statements given by almost a third of our A23 teachers: according to them, the exam administrated at the end of their CPIA's language courses is unreliable.

As it has been highlighted by Goffredo Buccini (2016), the comparison of the results of the Italian language tests conducted by 10 CPIAs in agreement with the local prefecture in February 2016 confirm what has been stated up to now. Taking the data presented in Table 1 into account, it is evident that the uneven score distribution hinders any possible comparability.

Table 1. CPIA's Italian language tests (February 2016)

\begin{tabular}{|l|c|c|c|c|c|}
\hline \multirow{2}{*}{\multicolumn{1}{|c|}{ City }} & \multirow{2}{*}{ Students } & \multicolumn{2}{c|}{$\begin{array}{c}\text { Students } \\
\text { who passed the exam }\end{array}$} & \multicolumn{2}{c|}{$\begin{array}{c}\text { Students } \\
\text { who failed the exam }\end{array}$} \\
\cline { 3 - 6 } & & $\mathbf{N}$ & $\%$ & $\mathbf{N}$ & $\%$ \\
\hline Bolzano & 5.388 & 3.826 & 71,3 & 1.562 & 28,7 \\
\hline Brescia & 23.362 & 15.973 & 72,3 & 7.889 & 27,3 \\
\hline Enna & 206 & 206 & 100 & 0 & 0 \\
\hline Milano & 60.051 & 47.172 & 78,6 & 12.879 & 21,4 \\
\hline Modena & 10.474 & 7.769 & 27 & 2.705 & 25 \\
\hline Napoli & 12.273 & 10.956 & 89,3 & 1.317 & 10,7 \\
\hline Padova & 10.684 & 7.536 & 70,5 & 3.148 & 29,5 \\
\hline Palermo & 4.616 & 4.017 & 87,1 & 599 & 12,9 \\
\hline Roma & 39.446 & 34.316 & 87 & 5.130 & 13 \\
\hline Reggio Calabria & 5.538 & 4.700 & 85 & 838 & 15 \\
\hline
\end{tabular}

As underlined by Sabrina Machetti and Lorenzo Rocca (2017), these weaknesses are the result of a significant lack on the field of language testing and assessment. It is clear that teachers who lack a suitable training in assessment and evaluation are involved on testing and assessment activities. 


\section{FINAL CONSIDERATIONS}

Our data demonstrates that current CPIA courses of Italian for foreigners do not always ensure an excellent quality language testing and assessment. To be more accurate, all the deficiencies previously outlined hinder the assessment carried out for the placement tests and the final exams.

Considering the key role that language testing and assessment have particularly on life of vulnerable learners, it is important to deal with these crucial aspects. In fact, as underlined in this paper, a good assessment is fundamental both to tailor the best didactic planning and facilitating the granting of the permanent residence permit and the citizenship.

Despite the efforts and dedication of many CPIA teachers, various aspects do not seem to work. Firstly, it appears that several of the weaknesses illustrated in this article, such as the language testing and assessment, are caused by the low-quality teacher training, which calls for reform and reorganisation of the CPIA regulations. The requirements for being a CPIA teacher should be completely reconsidered, that is to say it should be mandatory to have a degree and to be appropriately qualified. Secondly, as often underlined in our survey, many systemic problems can be related to the lack of coherent national CPIA rules and standards.

\section{REFERENCES}

ALTE (2016). Language tests for access, integration and citizenship: An outline for policy makers. Cambridge: Association of Language Testers in Europe.

Andreoletti, C. (2018). Il docente A23: formazione e competenze. Italiano a Stranieri, 23, 15-19.

Beacco, J.C. / Krumm, H.J. / Little, D. / Thalgott, P. (2017). The linguistic integration of adult migrants. Some lessons from research. Berlin: De Gruyter Mouton.

Borri, A. / Minuz, F. (2017). Literacy and language teaching: Tools, implementation and impact. In: J.C. Beacco / H.J. Krumm / D. Little / P. Thalgott (eds.), The linguistic integration of adult migrants. Some lessons from research (pp. 357-364). Berlin: De Gruyter Mouton.

Borri, A. / Minuz, F. / Rocca, L. / Sola, C. (2014). Italiano L2 in contesti migratori. Sillabo e descrittori dall'alfabetizzazione all'A1. Torino: Loescher Editore.

Brichese, A. (2019). Dalla parte dello studente: caratteristiche dello studente analfabeta e bassamente scolarizzato. In: F. Caon / A. Brichese (eds.), Insegnare italiano ad analfabeti (pp. 23-32). Torino: Bonacci editore.

Buccini, G. (2016). Esami troppo facili, risultati dubbi. I migranti alla lotteria dell'italiano. Corriere della Sera, 23 February. https://www.corriere.it/cronache/16_febbraio_23/migranti-scuolaistruzione-6abb6df6-d9aa-11e5-b385-82888b0a9701.shtml / [access: 31.10.2020].

Caon, F. (2019). Dalla parte del docente: Didattica dell'italiano L2 a studenti analfabeti e bassamente scolarizzati. In: F. Caon / A. Brichese (eds.), Insegnare italiano ad analfabeti (pp. 33-46). Torino: Bonacci editore. 
Caon, F. / Brichese, A. (2019). Insegnare italiano ad analfabeti. Torino: Bonacci editore.

Colosio, O. (2015). Il nuovo sistema di istruzione degli adulti. Dai CTP ai CPIA. Torino: Loescher Editore.

Council of Europe (2001). Common European framework of reference for languages: Learning, teaching, assessment. Cambridge: Cambridge University Press.

Council of Europe (2017). Language support for adult refugees: A Council of Europe toolkit. http: coe. int/en/web/language-support-for-adult-refugees [access: 31.10.2020].

Council of Europe (2018). Common European framework of reference for languages: Learning, teaching, assessment. Companion volume with new descriptors. http: rm.coe.int/cefr-companion-volumewith-new-descriptors-2018/1680787989 [access: 31.10.2020].

D'Agostino, M. (2017a). Analfabeti nell'Italia di ieri e di oggi. Dati, modelli, persone, parole. La lezione di Tullio De Mauro. Bollettino del Centro di studi filologici e linguistici siciliani, 28, 35-58.

D'Agostino, M. (2017b). L'italiano e l'alfabeto per i nuovi arrivati. Testi e linguaggi, 11, 141-156.

Ennas, G. (2019). Analfabeti e bassamente scolarizzati: la dimensione organizzativo formativa per la gestione di minori e adulti nei CPIA. In: F. Caon / A. Brichese (eds.), Insegnare italiano ad analfabeti (pp. 213-218). Torino: Bonacci editore.

Fritz, T. / Donat, D. (2017). What migrant learners need. In: J.C. Beacco / H.J. Krumm / D. Little / P. Thalgott (eds.), The linguistic integration of adult migrants. Some lessons from research (pp. 163-168). Berlin: De Gruyter Mouton.

Hogan-Brun, G. / Mar-Molinero, C. / Stevenson, P. (2009). Discourses on language and integration. Amsterdam: John Benjamins.

Lo Duca, M.G. (2013). Lingua Italiana ed educazione linguistica. Roma: Carocci.

Machetti, S. / Rocca, L. (2017). Integration of migrants, from language proficiency to knowledge of society: The Italian case. In: J.C. Beacco / H.J. Krumm / D. Little / P. Thalgott (eds.), The linguistic integration of adult migrants. Some lessons from research (pp. 213-218). Berlin: De Gruyter Mouton.

Masillo, P. (2017). Linguistic integration and residence policies in Italy: Issues and perspectives. In: J.C. Beacco / H.J. Krumm / D. Little / P. Thalgott (eds.), The linguistic integration of adult migrants. Some lessons from research (pp. 257-264). Berlin: De Gruyter Mouton.

Minuz, F. / Rocca, L. / Borri, A. (2019). Sillabi per l'alfabetizzazione in L2 in Italia e in Europa. In: F. Caon / A. Brichese (eds.), Insegnare italiano ad analfabeti (pp. 59-66). Torino: Bonacci editore.

MIUR (2017). Anticipazione sui principali dati della scuola statale. Anno Scolastico 2017/2018.

MIUR (2018). Principali dati della scuola. Avvio Anno Scolastico 2018/2019.

Naeb, R. / Young-Scholten, M. (2017). International training of teachers of low-educated adult migrants. In: J.C. Beacco / H.J. Krumm / D. Little / P. Thalgott (eds.), The linguistic integration of adult migrants. Some lessons from research (pp. 419-424). Berlin: De Gruyter Mouton.

Porcaro, E. (2019). Adulti stranieri analfabeti o debolmente alfabetizzati nei CPIA: Aspetti normativi. In: F. Caon / A. Brichese (eds.), Insegnare italiano ad analfabeti (pp. 193-204). Torino: Bonacci editore.

Pulinx, R. / Avermaet, P.V. (2017). The impact of language and integration policies on the social participation of adult migrants. In: J.C. Beacco / H.J. Krumm / D. Little / P. Thalgott (eds.), The linguistic integration of adult migrants. Some lessons from research (pp. 59-66). Berlin: De Gruyter Mouton.

Rocca, L. (2019). La gestione della fase di accoglienza dell'utenza vulnerabile: intervista e test. In: F. Caon / A. Brichese (eds.), Insegnare italiano ad analfabeti (pp. 69-88). Torino: Bonacci editore.

Rocca, L. / Carlsen, C.H. / Deygers, B. (2020). Linguistic integration of adult migrants: Requirements and learning opportunities. Report on the 2018 Council of Europe and ALTE survey on language and knowledge of society policies for migrants. Brussels: Council of Europe. 
Shohamy, E. (2001). The power of tests: A critical perspective on the uses of language tests. Harlow: Pearson Education.

Shohamy, E. (2009). Language tests for immigrants: Why language? Why tests? Why citizenship? In: G. Hogan-Brun / C. Mar-Molinero / P. Stevenson (eds.), Discourses on language and integration (pp. 45-59). Amsterdam: John Benjamins.

Shohamy, E. (2017). Critical language testing. In: E. Shohamy / I.G. Or / S. May (eds.), Language testing and assessment (3rd ed.) (pp. 441-454). Berlin: Springer.

Shohamy, E. / Or, I.G. / May, S. (2017). Language testing and assessment (3rd ed.). Berlin: Springer.

Troncarelli, D. / La Grassa, M. (2018). La didattica dell'italiano nel contatto interculturale. Bologna: Il Mulino.

Received: 30.03 .2020 ; revised: 12.10 .2020

\section{IGOR DEIANA}

Università per Stranieri di Perugia

igor.deiana@unistrapg.it

ORCID: 0000-0002-8050-4529

STEFANIA SPINA

Università per Stranieri di Perugia

stefania.spina@unistrapg.it

ORCID: 0000-0002-9957-3903 
